\title{
PUGHEADED SPOTTED SEA TROUT IN NORTH CAROLINA
}

\author{
FRANK J. SCHWARTZ and DUSTIN JONES \\ University of North Carolina \\ Institute of Marine Sciences \\ Morehead City, North Carolina 28557-3209
}

Pugheadedness was first reported in the fresh water fish, carp (Cyprinus carpio Linnaeus, 1758, family Cyprinidae) in 1554 (Fig. 1) (Gudger 1928). Other species have exhibited pugheadedness (Gudger 1930), most notably the marine fish, Striped Bass (Morone saxatilis Walbaum, 1796, family Moronidae) Gudger 1930; Manuseti 1960; Lyman 1960; Cheek 1966).

Pugheadedness, to date, has been reported for two female spotted Sea Trout (Cynoscion nebulosus Linnaeus, 1830, family Sciaenidae) caught by hook and line in Louisiana (Rose and Harris 1968; Hine and Shepard
1980; Overstreet 1983). Sizes were: $392 \mathrm{~mm} \mathrm{SL} \mathrm{caught}$ by Rose and Harris (1968) 396 mm SL, 841 g. caught by Hine and Shepard 1980).

Cheek (1966) reported the only pugheaded fish caught in North Carolina, a Striped Bass. A Spotted Sea Trout (NCMS 74131), that ranges from New York south to the Gulf of Mexico (McEachran and Fechhelm 1989) exhibiting pugheadedness was caught 14 January 2013 on an artificial lure while fishing unpolluted Smyrna creek, a short tributary that enters Core Sound, Carteret County, North Carolina. It was $323 \mathrm{~mm} \mathrm{SL}, 358 \mathrm{~mm} \mathrm{Tl}$, weight $569 \mathrm{~g}$.

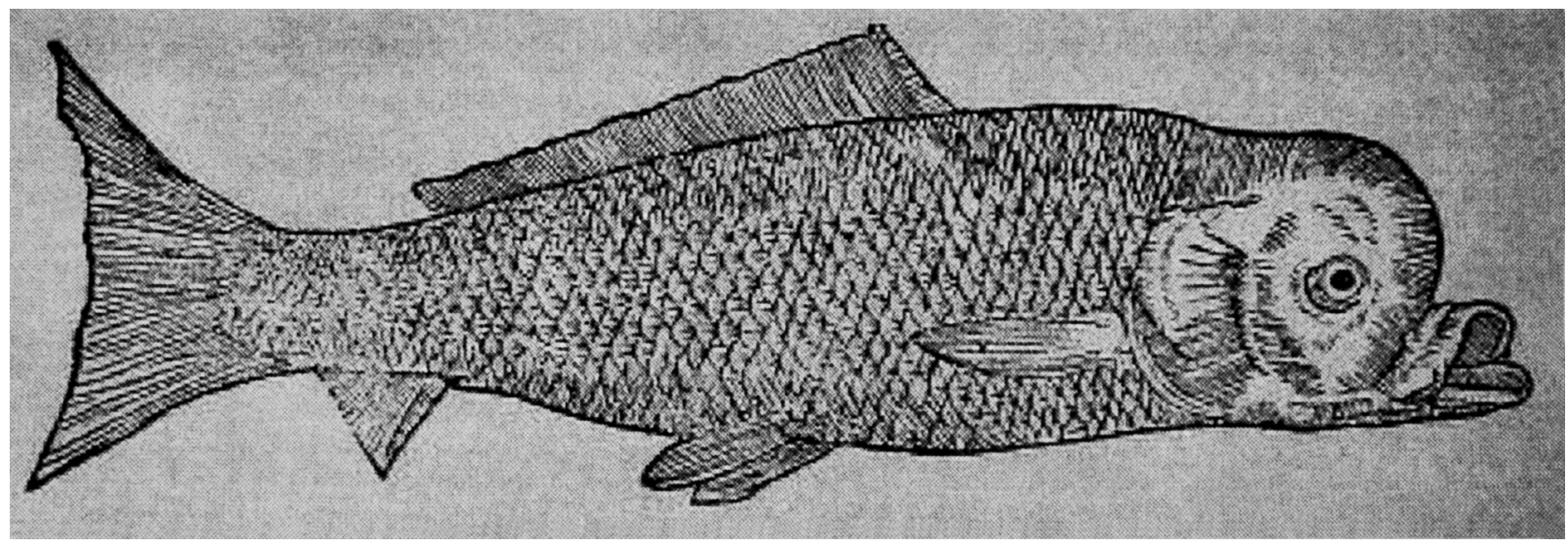

FIG. 1. 1554 Pug-headed Carp in Gudger (1928).

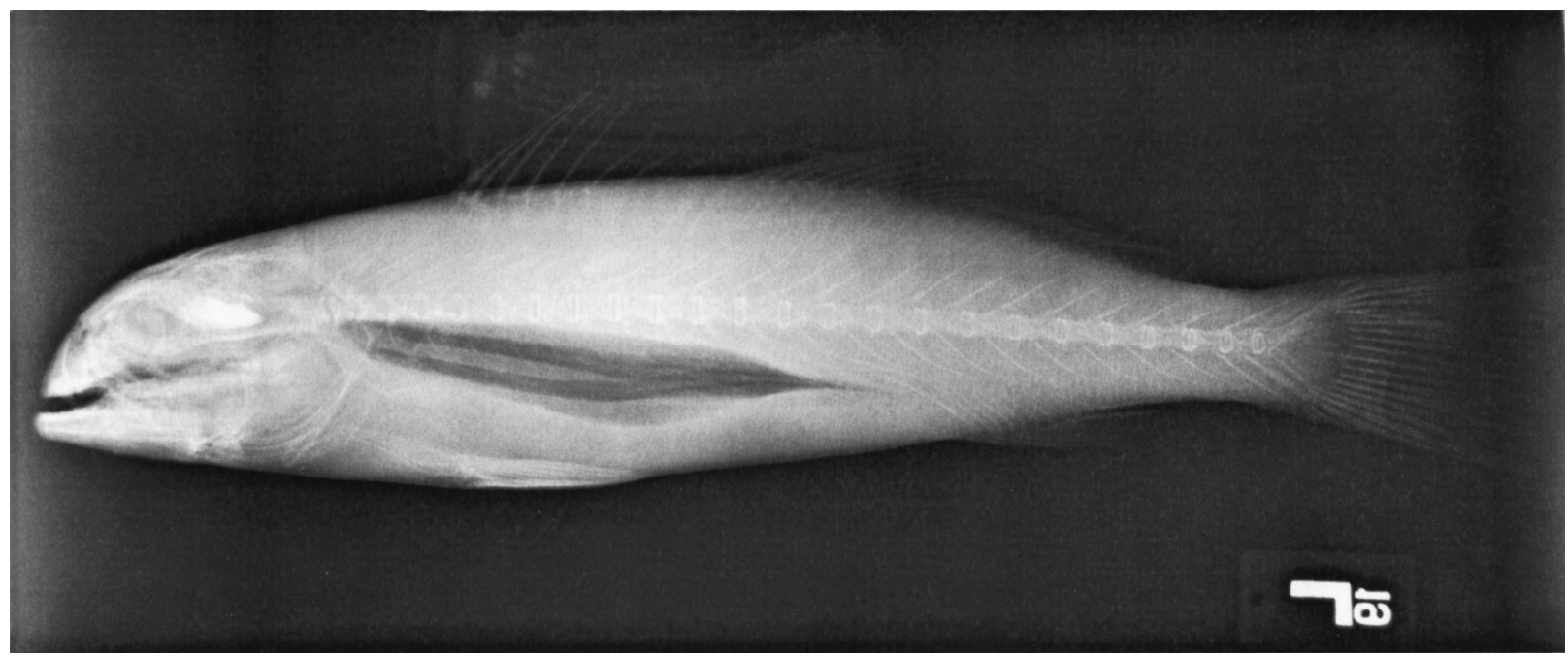

FIg. 2. Pugheaded Spotted Sea Trout caught in Smyrna Creek, N.C. 
Table 1. Morphologic and meristic comparisons between "normal" and pugheaded Spotted Sea Trout in North Carolina, expressed in $\% \mathrm{SL}$.

\begin{tabular}{lc}
\hline \multicolumn{1}{c}{ Normal } & Pugheadediness \\
\hline Head 30-33 & 28 \\
Snout 8-9 & 8 \\
Eye diameter 5-7 & 4.8 \\
Interorbital distance 5-6 & 7.2 \\
Upper jaw 12-15 & 10.5 \\
Body Depth 21-26 & 24.9 \\
Pectoral fin length 15 & 14.1 \\
Pectoral fin rays 15-18 & 15 \\
Dorsal 1 spines 1-8 & $1-9$ \\
D 1 rays 25-28 & 24 \\
Anal rays 10-11 & 8 \\
SL & 333 \\
TL & 390 \\
Weight & $529 \mathrm{~g}$ \\
\hline
\end{tabular}

External and x-ray examination (Fig. 2) of the pugheaded Spotted Sea Trout found extreme shortening of the head, snout, small eyes, shortened upper jaws and greater inter-orbital distances (Table 1). Other features of the pugheaded Spotted Sea Trout were similar to "normal specimens" except for dorsal and ray fin counts (Table 1).

Mansueti (1960) postulated that pugheadedness was the result of environmental conditions and heredity, not physical injury. Thus, the reasons pugheadednes occurred in the Spotted Sea Trout in North Carolina remains a mystery.
Acknowledgments: J. Francesconi (NCDNR) appreciated the value of the pugheaded Spotted Sea Trout and called it to our attention. E. Fuge and C. Williams (Cartert County Community College) produced the $\mathrm{x}$ ray of the pugheaded Spotted Sea Trout; G. Hogue (NCMS) provided the catalog number for the spotted seatrout now housed in Raleigh, North Carolina. A. Rodriguez (IMS) produced Figure 1 photograhphically.

\section{LITERATURE CITED}

CHEEK, R. P. 1966. Pugheaded Striped Bass in North Carolina. Wildlife NC. June, 1987. 7 p.

GUDGER, E. W. 1928. Guillaume Rondelet's pugheaded carp: the earliest record A.D. 1554. Natural Hist. 1928, 28:102-104.

GUDGER, E. W. 1930. Pugheadedness in the Striped Sea Bass Roccus lineatus and other related fishes. Bull. Am. Mus. Nat. Hist. 61(1):1-19.

HINE, S., AND J. SHEPHARD. 1980. Additional record of Pugheadedness in the Spotted Seatrout Cynoscion nebulosus. La. Wildl. Tech. Bull. Pp. 82-83.

LYMAN, H. 1961. A sixteen pound pugheaded Striped Bass from Massachusetts. Ches. Sci. 2(1-2):101-102.

MANUSETI, R. J. 1960. An unusually large pugheaded Striped Bass, Roccus saxatilis, from Chesapeake Bay, Marlyland. Ches. Sci. 1(2):111-113.

McEACHRAN, J. D., AND J. D. FECHHELM. 1989. Fishes of the Gulf of Mexico Vol. 2. Texas Univ. Press, Austin, Texas. $1140 \mathrm{p}$.

OVERSTREET, R. B. 1988. Aspects of the Spotted Seatrout Cynoscion nebulosus in Mississippi. Gulf Res. Rept. Supl. 1-40.

ROSE, C. D., AND A. H. HARRIS. 1968. Pugheadedness in the Spotted Sea Trout. Quart. J. Fla. Acad. Sci. 31(4):268-270. 